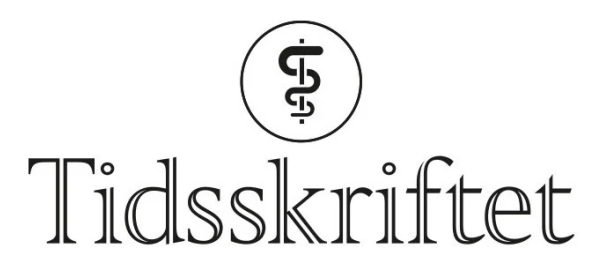

DEN NORSKE LEGEFORENING

\title{
En dramatisk sykdomsopplevelse
}

PERSONLIGE OPPLEVELSER

ASBJØRN MAGNAR ROTEVATN

Email:asrot@online.no

Nattlandsfjellet go c

5098 Bergen

\section{2005 ble jeg rammet av subaraknoidalblødning. Takket være dyktige kolleger gikk det bra, men kontrollopplegget etter slik blødning bør kanskje suppleres med rutinemessig undersøkelse av kognitive funksjoner.}

Lørdag 5. mars 2005 var i utgangspunktet som mange andre lørdager. På formiddagen reiste jeg til fastlegekontoret for å skrive noen henvisninger og ble som vanlig sittende noen timer. Om kvelden var vi bedt i selskap. Like etter ankomst, mens jeg sto og pratet med en av de andre gjestene, fikk jeg plutselig en voldsom, sprengende hodepine. Det var som å slå på en bryter. Smerten var intens. Like etter at vi hadde satt oss til bords begynte jeg å kaldsvette, og jeg skjønte intuitivt at jeg hadde fått hjerneblødning. Velkomstskålen måtte for mitt vedkommende utsettes til en annen gang. Jeg ba min kone bli med ut på gangen og ringe 113 .

I ambulansen fikk jeg oksygen som lindret smertene noe. Ambulansepersonellet fikk underveis beskjed om å kjøre direkte til akuttmottaket. Inni meg trakk jeg et lettelsens sukk; jeg ante at ting begynte å haste.

\section{På sykehuset}

Blått undersøkelsesrom, masse helsepersonell rundt sengen, en vennlig stemme hørtes: «Hei, Asbjørn.» Kvinnen som eide stemmen var vakthavende nevrokirurg. Jeg rakk å fortelle litt om symptomene før jeg mistet bevisstheten. Umiddelbart før jeg besvimte følte jeg at hodet ville sprenges og jeg hadde begynt å brekke meg. Lite ante jeg at det hadde blitt ropt «STANS!» da jeg besvimte - en lite hyggelig opplevelse for en ektefelle som er sykepleier.

Den diagnostiske prosess gikk sin gang mens jeg fortsatt var bevisstløs. CT-bildene viste subaraknoidalblødning og begynnende hydrocephalus. CT-angiografi viste blødning fra et aneurisme på basilaristoppen. 
Et par timer senere forklarte vakthavende nevroradiolog og nevrokirurg at jeg skulle opereres med coiling neste morgen. Jeg var våken og befant meg på nevrokirurgisk overvåkingsavdeling. Jeg lå med ledninger og slanger i alle ekstremiteter, lumbaldren for drenasje av spinalvæske, og en rekke medisinske variabler ble overvåket.

En beroligende anestesilege informerte før den generelle narkosen ble innledet. Lørdag natt var blitt til søndag morgen og en meget avansert medisinsk prosedyre sto for døren. For første gang kjente jeg litt på redselen. Innføring av coiler, spiralformede platinatråder, via et tynt kateter fra femoralarterien til et lite aneurisme på a. basilaris i bakre skallegrop virket nesten hasardiøst. Bevissthetsnivået var fortsatt nedsatt, så jeg forsto nok ikke inngrepets kompleksitet før lenge etterpå. Kan hende var det best slik.

I ettertid vet jeg at coilingen var teknisk vanskelig fordi aneurismet var lite, men med bred hals. Noen timer senere denne søndagen kunne overlegen i intervensjonsnevroradiologi, som utførte prosedyren, ringe hjem til min kone og fortelle at det hadde gått svært bra. Lettelsen var stor!

\section{Etter operasjonen}

Etter ti døgn ble jeg utskrevet fra universitetssykehuset uten nevrologiske utfall, men temmelig utmattet og med tre måneders full sykmelding. De første dagene hjemme ble jeg lett sliten og klarte kun noen få skritt utenfor huset. Den fysiske fremgangen var jevn og god, og etter tre måneder var jeg ikke så langt fra min fysiske tilstand før blødningen.

I ettertid har jeg tenkt mye på, og er takknemlig for, at det i Norge finnes spesialavdelinger som ved avanserte metoder kan behandle de relativt få av oss som rammes av denne dramatiske sykdommen. Likevel dør nesten halvparten av alle som rammes. Det er ikke vanskelig å tenke seg at det kreves faglig dyktighet og mye spesialkompetanse for å håndtere subaraknoidalblødninger optimalt.

«Men hvordan går det med det kognitive da, Asbjørn?» Spørsmålet ble stilt av en god fastlegekollega tre måneder etter blødningen. På medisinstudiet i 1970-årene lærte vi inngående om de dramatiske akuttsymptomene, og om mulig fatalt utfall, men kognitive problemer ble vel knapt nevnt. På dette tidspunktet opplevde jeg som sagt fin fysisk fremgang og glemte derfor vår lille telefonsamtale inntil flere måneder senere.

Fem måneder etter hjerneblødningen startet jeg opp i fastlegepraksisen med $50 \%$ sykmelding. Jeg så frem til å treffe pasienter og kolleger. Jeg trodde at jeg ville være tilbake i full stilling etter få måneder. Jeg var derfor ganske uforberedt da jeg snart merket redusert tempo i arbeidet og redusert stresstoleranse. Den totale arbeidskapasiteten var heller ikke som før og jeg ble fortere trett.

Problemene vedvarte over tid og etter ca. to år, med flere typer kontakter i helsevesenet, der ikke minst min fastlege var til stor hjelp, bestemte jeg meg for å avvikle fastlegepraksisen og gå over i roligere type legearbeid, kombinert med gradert uføreytelse.

\section{Refleksjoner}

I årene som er gått siden hjerneblødningen har jeg vært til rutinemessige etterkontroller med MR-undersøkelser og cerebral angiografi. Jeg har fått skriftlige tilbakemeldinger fra min kontaktlege ved nevrokirurgisk avdeling. Ordningen med kontaktlege har vært betryggende for meg som pasient.

Vanskelighetene jeg opplevde ved oppstart i allmennpraksis etter hjerneblødningen har avstedkommet noen tanker. Burde kontrollopplegget etter subaraknoidalblødning vært supplert med rutinemessig undersøkelse av kognitive funksjoner? Jeg fikk for egen del drøftet mitt problem med min kontaktlege ved nevrokirurgisk avdeling i forbindelse med ettårskontrollen og ble da henvist til adekvate undersøkelser. Fagpersoner som jobber med 
nevrorehabilitering burde imidlertid kanskje vurdere hvorvidt rutinemessig undersøkelse av kognitive funksjoner bør være en del av kontrollopplegget etter subaraknoidalblødning. $\AA ̊$ avdekke forhold som redusert arbeidstempo, endret stresstoleranse og redusert arbeidskapasitet er viktig, både i forhold til arbeidslivet og i forhold til pasientens nærmeste.

Når man er så heldig å komme gjennom denne sykdommen uten synlige nevrologiske utfall, er det lett, både for en selv og for andre, å tro at man fungerer bedre enn man i virkeligheten gjør. Kognitive vansker er ikke så lett synlige! Like fullt var jeg heldig som overlevde! Subaraknoidalblødning er en tøff opplevelse, både fysisk og psykisk, psykisk også for de nærmeste. Jeg var kritisk syk, men opplevde at jeg nærmest fikk livet tilbake i gave.

Publisert: 11. juni 2009. Tidsskr Nor Legeforen. DOI:10.4045/tidsskr.08.0615

Manuskriptet ble mottatt 3.12. 2008 og godkjent 8.1. 2009. Medisinsk redaktør Erlend Hem.

(C) Tidsskrift for Den norske legeforening 2023. Lastet ned fra tidsskriftet.no 26. april 2023. 